\title{
ANALISIS FAKTOR-FAKTOR YANG MEMPENGARUHI \\ PENGEMBANGAN KAWASAN EKOWISATA ALAM PUCAK \\ DIKECAMATAN TOMPOBULUKABUPATEN MAROS
}

\section{Eliza Meiyani}

\begin{abstract}
ABSTRAK
Dalam pembangunan nasional dijelaskan bahwa kepariwisataan bertujuan untuk menggalakkan perekonomian nasional dan daerah. Berdasarkan pengalaman pada tahun-tahun lalu, terutama krisis moneter melanda perekonomian Indonesia, kegiatan kepariwisataan memiliki potensi besar dalam peningkatan perekonomian nasional yang salah satunya pendorongnya adalah globalisasi diberbagai sektor. Pariwisata telah menjadi bagian penting dari kebutuhan dasar masyarakat maju dan sebagian kecil masyarakat negara berkembang. Pariwisata semakin berkembang sejalan perubahan-perubahan sosial, budaya, ekonomi teknologi dan politik. Ditemukannya teknologi transportasi, dan peningkatan waktu luang yang didorong oleh penciutan jam kerja, telah mempercepat mobilitas manusia antar daerah, negara dan benua.

Ekowisata merupakan salah satu bentuk kegiatan khusus yang menaruh perhatian besar terhadap kelestarian sumber daya pariwisata. Dalam meningkatkan kesejahteraan masyarakat lokal. Dengan kata lain ekowisata adalah bentuk industri pariwisata berbasis lingkungan yang memberikan dampak kecil bagi kerusakcm alam dan budaya lokal sekaligus menciptakan peluang kerja dan pendapatan serta membantu kegiatan konservasi alam itu sendiri.
\end{abstract}

\section{A. Pendahuluan}

Sebagai suatu aktivitas manusia, pariwisata adalah fenomena pergerakan manusia, barang dan jasa yang sangat kompleks. Hal ini terkait dengan organisasi, hubungan kelembagaan individu, kebutuhan layanan. Penyediaan kebutuhan layanan, dan sebagainya. Semua ini merupakan rangkaian elemen yang saling mempengaruhi dalam menjalankan fungsi-fungsi tertentu, sehingga pemerintah tersebut membentuk suatu sistem yang disebut sebagai sistem pariwisata. Hal ini memberikan arti bahwa penggalakan kegiatan kepariwisataan akan meningkatkan kegiatan ekonomi masyarakat dan sekaligus berperan dalam upaya peningkatan kesejahteraan dan pendapatan masyarakat. Peran serta pihak swasta dan pemerintah dalam penyelenggaraan pembangunan kepariwisataan perlu lebih 
ditingkatkan dan dikembangkan dalam akhir kompetisi yang sehat dan didasari dengan komitmen saling menguntungkan serta saling menghidupi.

Keadaan diatas tentunya saling menghidupi merupakan suatu perkiraan yang realitas, dengan asumsi bahwa secara umum perkiraan sasaran pembangunan adalah untuk meningkatkan kegiatan ekonomi masyarakat dengan indikator peningkatan kesejahteraan dan pendapatan masyarakat.

Banyak daerah berambisi menjadikan pariwisata sebagai sektor andalan, tetapi dalam kenyataan mereka tidak mempunyai pemahaman dan kemampuan yang memadai untuk mengembangkan pariwisatanya. Produk apa yang dikembangkan, mengapa demikian dan bagaimana cara pengembangannya. Semua masih merupakan teka-teki yang harus dibatasi hampir semua daerah. Oleh karena itu perencanaan menjadi salah satu masalah yang strategis dan mutlak diperlukan.

Ide-ide itu kemudian dituangkan kedalam konsep pariwisata berkelanjutan artinya adalah pembangunan sumber daya (atraksi, aksesibilitas, amenitas) pariwisata yang bertujuan untuk memberikan keuntungan optimal bagi pemangku kepentingan (stake holder) dan nilai kepuasan optimal bagi wisatawan jangka panjang. Jadi pariwisata hanya dapat bertahan lama atau berkelanjutan jika ia memberikan kepuasan bagi wisatawan dalam jangka panjang dalam bentuk pengalaman yang lengkap (total experience). Pemanfaatan sumber daya tersebut harus pula melibatkan masyarakat lokal dan memberikan manfaat yang optimal bagi mereka.

Sulawesi selatan mempunyai potensi pariwisata yang cukup besar bagaikan harta terpendam yang jika lahannya dikelola secara tepat. Dari berbagai informasi yang diperoleh bahwa Kabupaten Maros memiliki keindahan panorama alam, kekayaan flora dan fauna yang mampu mempesona wisatawan, namun belum diekspoitasi dengan sentuhan keindahan wisata sehingga belum banyak mendapat kunjungan wisatawan.

Dengan menyangkut sektor pariwisata Kabupaten Maros sebagai 
salah satu kegiatan pembangunan, diyakini akan memberikan kontribusi terhadap perolehan asli daerah/PAD yang sangat berarti khususnya untuk kabupaten Maros dan bagi pemerintah Provinsi Sulawesi Selatan. Disamping itu akan mendorong peningkatan mutu sumber daya manusia masyarakat di daerah ini, terutama bagi kehidupan sosial ekonomi masyarakat yang berada di daerah sekitar wilayah perencanaan ekowisata tersebut.

Pengelolaan sarana dan prasarana rekreasi memiliki dampak positif khususnya dibidang ekonomi, sosial, dan budaya sekaligus berusaha mengoptimalkan dan mendayagunakan potensi lingkungan alam sebaikbaiknya, disamping itu tetap menjaga keseimbangan alam dari lingkungan baik yang berada pada kawasan itu sendiri maupun tempat-tempat sekitar Kawasan secara menyeluruh.

Salah satu objek wisata yang menarik dan memenuhi syarat untuk dapat dikembangkan karena memiliki potensi alam yang tidak kalah menarik dengan objek wisata lainnya adalah Kawasan Wisata Alam Puca' kawasan ini memiliki sumber daya alam yang kaya dan terdiri dari beberapa ekosistem yang relatif masih utuh dan asli. Beberapa ekosistem yang ada di lokasi kawasan wisata alam tersebut meliputi ekosistem hutan hujan dataran rendah dan tinggi dan ekosistem perbukitan, menjadikan kawasan ini kaya akan keanekaragaman hayati. Adapun beberapa potensi objek wisata terdapat di kawasan wisata alam adalah air terjun Bontomanurung, yang terletak di pegunungan di dukung oleh pemandangan alam yang indah dan hutan pinus dipadu dengan budaya masyarakat setempat yang masih terpelihara, area perkemahan \{Camping Ground), penjelajahan hutan, pengamatan flora dan fauna, agrowisata serta kegiatan di alam bebas (out bound), perpaduan dari potensi tersebut akan menghasilkan suatu kawasan wisata yang potensial khususnya dalam konsep pengembangan kawasan ekowisata alam Pucak, yang direncanakan akan dijadikan sebagai kebun raya, taffian safari dan agrowisata.

Kawasan ekowisata alam Pucak sebagai salah satu aset pariwisata perlu diperhatikan mengingat kawasan wisata ini memiliki daya tarik alami yang tidak 
dimiliki oleh objek wisata sejenis. Penanganan yang profesional atas aset pariwisata ini juga perlu ditingkatkan terutama perencanaan dan penataan yang berwawasan budaya.

Pentingnya aspek sosial ekonomi dalam industri pariwisata pada umumnya dan ekowisata pada khususnya. Memberikan pengaruh besar bagi kelangsungan kegiatan ekowisata yakni dengan meminimalkan dampak negative dan memaksimalkan dampak positif yang ditumbuhkan dari faktor eksternal dan internal. Untuk itu perlu adanya kebijakan yang mampu menyeimbangkan dan memelihara aliran manfaat (trade off) kepada penduduk lokal. Mereka perlu diberikan kesempatan aktif mengolah dan menjual produk wisata yang dibutuhkan oleh wisatawan. Masyarakat ekonomi sektor wisata sangat disignifikan sehingga aspek sosial dan lingkungan seringkali terabaikan, trade of aliran intensif ekonomi pada sektor prioritas umumnya lebih cenderung ke pemilik modal dibandingkan ke penduduk lokal. Trade off tersebut harus mengarah secara proporsional agar kegiatan ekowisata dapat berjalan dengan sesuai dengan tujuan yang diharapkan.

Oleh sebab itu faktor daya dukung ekonomi, sosial, budaya dan ekologi setempat dalam pemanfaatan kawasan untuk ekowisata menjadi mutlak baik secara jangka pendek maupun jangka panjang dalam mendukung tercapainya industri pariwisata yang berkelanjutan.

\section{A. Rumusan Masalah}

Berdasarkan uraian latar belakang diatas maka rumusan masalah yang diajukan adalah :

1. Faktor-faktor apa saja yang mempengaruhi pengembangan kawasan ekowisata alam Puca', yang meliputi: aksesibilitas, fasilitas, utilitas, atraksi, etika dan estetika, sumberdaya manusia danpromosi.

2. Atribut produk wisata manakah yang paling dominan dalam memberikan pengaruh terhadap pengembangan kawasan ekowisata alam Puca'.

\section{B. Tujuan Dan Kegunaan}

Adapun tujuan dari penulisan 
ini adalah :

1. Untuk menjelaskan pengaruh atribut produk wisata terhadap pengembangan kawasan ekowisata alam Pucak yang meliputi: aksesibilitas, fasilitas, utilitas, atraksi, etika dan estetika, sumberdaya manusia dan promosi.

2. Untuk mengetahui atribut produk wisata yang memiliki pengaruh paling dominan terhadap pengembangan kawasan ekowisata alam Pucak.

Kegunaan penelitian ini yaitu :

1. Sebagai acuan bagi pemerintah setempat dengan adanya pemahaman yang terkait dengan upaya pengembangan suatu kawasan Ekowisata.

2. Untuk digunakan sebagai bahan pertimbangan bagi pengelolah kawasan ekowisata alam Pucak dalam upaya pengembangan secara lebih optimal.

\section{Pembahasan}

1. Analisis Faktor-faktor yang Mempengaruhi Pengembangan Kawasan Ekowisata Alam Pucak Variabel penelitian terdiri dari dua, yaitu variabel bebas (X) dan variabel terikat (Y). Variabel bebas berupa "Potensi Kawasan Ekowisata Alam Pucak", dimana parametemya meliputi Aksesibilitas (XI), Fasilitas(X2), Utilitas(X3), Atraksi Wisata(X4), Etika dan Estetika(X5), SDM(X6) dan Promosi (X7), sedangkan variabel terikat dalam hal ini Motivasi Wisatawan (Y). Keseluruhan variabel akan dibahas pada bagian di bawah ini

a. Aksesibiltas (X1)

Dalam variabel aksesibilitas ini ada tujuh (7) kuesioner yang meliputi ; (1) kemudahan aksesibilitas, (2) kondisi jalan, (3) kenyamanan dan keamanan, (4) Waktu tempuh dan jarak pencapaian, (5) moda transportasi, (6) jumlah dan frekuesi transportasi.

Hasil jawaban responden mengenai aksesibilitas dapat dilihat pada tabel dibawah ini :
Tabel 1

Nilai rata-rata variabel

Aksesibilitas 


\begin{tabular}{|c|c|c|c|}
\hline Interval & Kategori & $\begin{array}{c}\text { Jumlah } \\
\text { Responden }\end{array}$ & $\%$ \\
\hline $1,00-$ & Tidak & & 2 \\
1,75 & Baik & 4 & \\
\hline $1,76-$ & Kurang & & \\
2,50 & Baik & 46 & 98 \\
\hline $2,51-$ & Baik & - & - \\
3,25 & & & \\
\hline $3,26-$ & Sangat & - & \\
4,00 & Baik & & \\
\hline
\end{tabular}

(Sumber : Data Primer yang diolah)

Dari tujuh indikator aspek aksesibilitas tersebut, akan dirangkum secara umum bagaimana nilai rata-rata tanggapan responden terhadap aspek aksesibiltas (lihat rata-rata aksesibiltas pada lampiran) yang kemudian diberi interval empat, yaitu $1,00-1,75=$ tidak baik; 1,76 250 -kurang baik; 2,51 - 3,25= baik; dan 3,26-4,00 = sangat baik.

Dari tabel di atas terlihat bahwa secara umum, aspek aksesibilitas berdasarkan nilai rata-rata variabel aksesibitas adalah tidak baik dan kurang baik, dengan persentase sebesar \% atau . dengan kata lain terdapat responden yang nilai rata- ratanya antara 1,76-2,50.

b. Fasilitas (X2)

Dalam variabel Fasilitas ini, ada lima (5) kuesioner yang meliputi : (1) Keberadaan Fasilitas, (2) Jumlah Dan Jenis Fasilitas, (3) Kondisi Dan Kualitas Fasilitas, (4) Kemudahan Dan Biaya Fasilitas, (5) Tingkat Dan Kenyaman Fasilitas.

Hasil jawaban responden mengenai Fasilitas dapat dilihat pada tabel dibawah ini :

Tabel 2

Nilai Rata-Rata Variabel Fasilitas

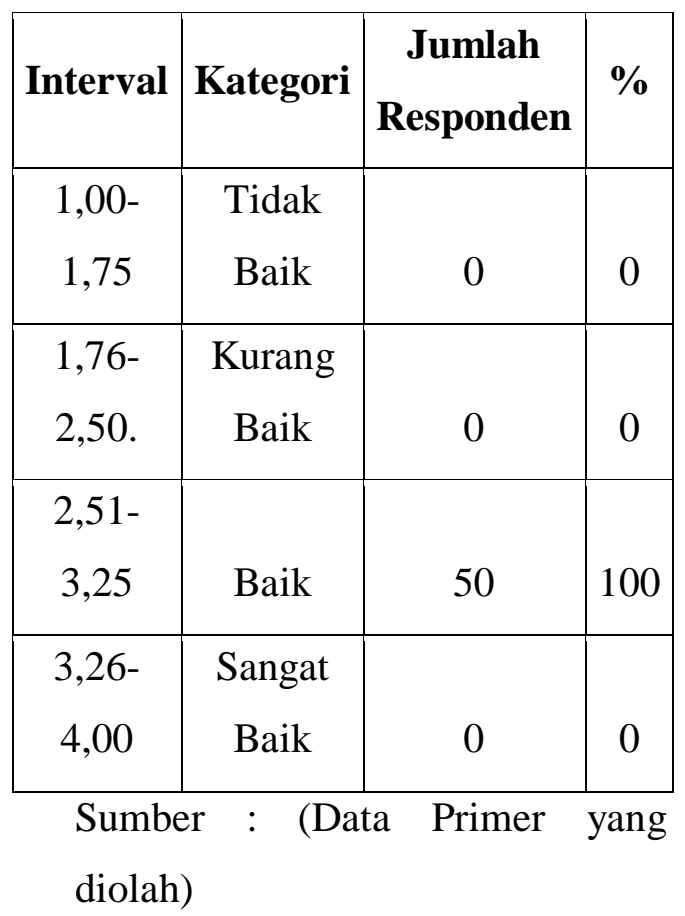

Dari tabel di atas terlihat 
bahwa secara umum, fasilitas di Kawasan Ekowisata Alam Puca yang meliputi 1) Keberadaan Fasilitas, (2) Jumlah Dan Jenis Fasilitas, (3) Kondisi Dan Kualitas Fasilitas, (4) Kemudahan Dan Biaya Fasilitas, (5) Tingkat Dan Kenyaman Fasilitas yang diberikan berdasarkan nilai rata-rata variabel fasilitas adalah cukup baik, dengan persentase sebesar $100 \%$ atau dengan kata lain terdapat 50 responden yang nilai rata-ratanya antara 2,51-3,25 yang menjawab bahwa fasilitas yang ditawarkan kepada wisatawan sudah cukup baik.

c. Utilitas (X3)

Dalam variabel Utilitas ini, ada lima (5) kuesioner yang meliputi : (1) Kondisi Infrastruktur, (2) Jangkauan Pelayanan Air Bersih, (3) Jangkauan Pelayanan Listrik, (4) Kualitas Pelayanan Air Bersih, (5) Kepuasan Pelayan air Bersih.

Hasil jawaban responden mengenai Fasilitas dapat dilihat pada tabel dibawah ini :

Tabel 3 Nilai Rata-Rata Variabel Utilitas

\begin{tabular}{|c|c|c|c|}
\hline Interval & Kategori & $\begin{array}{c}\text { Jumlah } \\
\text { Responden }\end{array}$ & $\%$ \\
\hline $1,00-$ & Tidak & & \\
1,75 & Baik & 0 & 0 \\
\hline $1,76-$ & Kurang & & \\
2,50 & Baik & 0 & 0 \\
\hline $2,51-$ & & 50 & 100 \\
3,25 & Baik & Sangat & 0 \\
\hline $3,26-$ & Baik & 0 & 0 \\
4,00 & Sumber (Data Primer yang \\
diolah)
\end{tabular}

Dari tabel di atas terlihat bahwa secara umum, Utilitas di Kawasan Ekowisata Alam Puca yang meliputi : (1) Kondisi Infrastruktur, (2) Jangkauan Pelayanan Air Bersih, Jangkauan Pelayanan Listrik, (4) Kualitas Pelayanan Air Bersih, (5) Kepuasan Pelayan air Bersih, yang diberikan berdasarkan nilai ratarata variabel Utilitas adalah baik, dengan persentase sebesar $100 \%$ atau dengan kata lain terdapat responden yang nilai rata-ratanya antara 2,51-3,25 yang menjawab bahwa Utilitas yang ditawarkan kepada wisatawan sudah baik.

d. Atraksi Wisata (X4) 
Dalam variabel lokasi ini, ada Lima (5) kuesioner yang meliputi : (1) Keragaman (Diversitas), (2) Keunikan (Otentisitas), Keaslian (Originalitas), (4) Kemudahan Dalam menikmati Atraksi Wisata, dan (5) Daya Tarik Atraksi Wisata Buatan. Hasil jawaban responden mengenai promosi dapat dilihat pada tabel di bawah ini :

\section{Tabel 4}

Nilai Rata-rata variabel Atraksi

\begin{tabular}{|c|c|c|c|}
\hline Interval & Kategori & $\begin{array}{c}\text { Jumlah } \\
\text { Responden }\end{array}$ & $\%$ \\
\hline $1,00-$ & Tidak & & \\
1,75 & Baik & 0 & 0 \\
\hline $1,76-$ & Kurang & & 6 \\
2,50 & Baik & 2 & \\
\hline $2,51-$ & & & 94 \\
3,25 & Baik & 48 & 0 \\
\hline $3,26-$ & Sangat & & \\
4,00 & Baik & 0 & 04 \\
\hline
\end{tabular}

(Sumber : Data Primer yang diolah)

Dari tabel di atas terlihat bahwa secara umum, atraksi yang ada di Kawasan Ekowisata Alam Puca yang meliputi :
Keragaman (Diversitas),

keunikan (Otentisitas),

Keaslian

(Originalitas),

(4)Kemudahan Dalam menikmati Atraksi Wisata, dan (5) Daya Tarik Atraksi Wisata Buatan, berdasarkan nilai rata-rata variabel Atraksi adalah baik, dengan persentase sebesar $94 \%$ atau dengan kata lain terdapat 48 responden yang nilai rata-ratanya antara 2,51-3,25 yang menjawab bahwa Atraksi yang ada di Kawasan ekowisata alam Puca, selama ini sudah Baik. Ini berarti Kawasan ekowisata alam Puca sudah mempunyai Basic yang kuat dalam hal potensi pengembangan ekowisata yang beraneka ragam dan terjaga keasliannya.

e. Etika dan Estetika (X5)

Dalam variabel sarana fisik ini, ada lima (5) kuesioner yang meliputi : (1)Tingkat kepedulian Masyarakat, (2) Kondisi Kebersihan, (3) Keramah tamahan Masyarakat, (4) Keunikan Alam dan Atraksi, dan (5) Kondisi Budaya dan Adat Istiadat.

Hasil jawaban responden mengenai etika dan estetika dapat 
dilihat pada tabel dibawah ini :

Tabel 5

Nilai Rata-rata variabel Etika

Dan Estetika (X5)

\begin{tabular}{|c|c|c|c|}
\hline $\begin{array}{c}\text { Interva } \\
\mathbf{l}\end{array}$ & Kategori & $\begin{array}{c}\text { Jumlah } \\
\text { Respond } \\
\text { en }\end{array}$ & $\%$ \\
\hline $\begin{array}{c}1,00- \\
1,75\end{array}$ & $\begin{array}{c}\text { Tidak } \\
\text { Baik }\end{array}$ & 0 & 0 \\
\hline $\begin{array}{c}1,76- \\
2,50\end{array}$ & $\begin{array}{c}\text { Kurang } \\
\text { Baik }\end{array}$ & 0 & 0 \\
\hline $2,51-$ & Baik & 42 & 94 \\
3,25 & & & 6 \\
\hline $3,26-$ & Sangat & & \\
4,00 & Baik & 8 & 6 \\
\hline
\end{tabular}

(Sumber : Data Primer yang diolah

Dari tabel di atas terlihat bahwa secara umum, etika dan estetika yang ada ada di Kawasan Ekowisata Alam Puca yang meliputi : (1)Tingkat kepedulian Masyarakat, (2)Kondisi Kebersihan, (3) Keramah tamahan Masyarakat, (4) Keunikan Alam dan Atraksi, dan (5) Kondisi Budaya dan Adat Istiadat, berdasarkan nilai rata-rata variabel etika dan estetika adalah cukup baik, dengan persentase sebesar 84 $\%$ atau dengan kata lain terdapat 42 responden yang nilai rataratanya antara 2,51-3,25 yang menjawab bahwa Etika dan estetika yang di Kawasan ekowisata alam Puca, selama ini Baik. Ini berarti di Kawasan ekowisata alam Puca etika dan estetika yang ada sangat dijaga baik oleh masyarakat setempat, sehingga norma-norma, kebiasaan dan adat - istiadat sejalan dengan pengembangan kawasan ekowisata alam Pucak yang berdasarkan pada konsevasi alam dan pemberdayaan alam yang bertanggung jawab dan suistanable (berkelanjutan).

f. Sumber Daya Manusia /SDM (X6)

Dalam variabel SDM ini, ada lima (5) kuesioner yang meliputi : (1) Tingkat keterampilan, (2) Tingkat kecakapan, (3) Tingkat Pengetahuan, (4) Tingkat Profesionalisme, (5) Tingkat Kerapihan Dan Kecepatan Hasil jawaban responden mengenai SDM dapat dilihat pada tabel dibawah ini

Tabel 6

Nilai Rata-Rata Variabel SDM 
dan memiliki pengetahuan sangat

\begin{tabular}{|c|c|c|c|}
\hline Interval & Kategori & $\begin{array}{r}\text { Jumlah } \\
\text { Responden }\end{array}$ & $\%$ \\
\hline $1,00-1,75$ & Tidak Baik & 0 & $0 \mathrm{~s}$ \\
\hline $1,76-2,50$ & $\begin{array}{c}\text { Kurang } \\
\text { Baik }\end{array}$ & 24 & 52 \\
\hline $2,51-3,25$ & Baik & 26 & 48 \\
\hline $3,26-4,00$ & Baik & 0 & 0 \\
\hline
\end{tabular}

terbatas dalam menangani Kawasan ekowisata alam Pucak, yang membutuhkan penangan yang serius mengingat pengembangan ekowisata ini berhubungan erat dengan sistem ekologi dan kelangsungan hidup habitat flora dan fauna yang ada disekitar Kawasan ekowisata alam Puca.

Sumber : (Data Primer yang g. Promosi (X7)

diolah)

Dalam variabel promosi ini,

Dari tabel di atas terlihat bahwa secara umum, SDM di Kawasan Ekowisata Alain Puca yang meliputi : (1) Tingkat keterampilan, (2) Tingkat kecakapan, (3) Tingkat Pengetahuan, (4) Tingkat Profesionalisme, (5) Tingkat Kerapihan Dan Kecepatan, yang diberikan berdasarkan nilai ratarata variabel SDM adalah berkisar kurang baik dan baik, dengan persentase masing -masing sebesar $24 \%$ atau dengan kata lain terdapat 52 responden yang nilai rata-ratanya antara 1,76-2,50 yang menjawab bahwa SDM yang ada di Kawasan Ekowisata Alam Pucak kurang terampil dan rapi ada lima (5) kuesioner yang meliputi : (1) Penyampaian Promosi, (2) frekuensi promosi, (3) Tingkat Keyakinan Kelengkapan Informasi, (5) Daya Tarik Promosi.

Hasil jawaban responden mengenai promosi dapat dilihat pada tabel ini.

Tabel 7

Nilai Rata-rata variabel Promosi

\begin{tabular}{|c|c|c|c|}
\hline Interval & Kategori & $\begin{array}{c}\text { Jumlah } \\
\text { Responden }\end{array}$ & $\%$ \\
\hline $1,00-$ & Tidak & & \\
1,75 & Baik & 29 & 60 \\
\hline $1,76-$ & Kurang & & \\
2,50 & Baik & 21 & 40 \\
\hline
\end{tabular}




\begin{tabular}{|c|c|c|c|}
\hline $\begin{array}{c}2,51- \\
3,25\end{array}$ & Baik & 0 & 0 \\
\hline $3,26-$ & Sangat & & \\
4,00 & Baik & 0 & 0 \\
\hline
\end{tabular}

(Sumber : Data Primer yang diolah)

Dari tabel di atas terlihat bahwa secara umum, promosi Kawasan Ekowisata Alam Puca berdasarkan nilai-rata-rata variabel promosi adalah Tidak baik, dengan persentase sebesar $60 \%$ atau dengan kata lain terdapat 29 responden yang nilai rata-ratanya antara 1.00-1,75 yang menjawab bahwa promosi yang dilakukan oleh Kawasan Ekowisata alam Puca selama ini tidak baik. Promosi Kawasan Ekowisata Alam Puca biasa menjadi salah satu faktor jasa yang dapat diandalkan untuk mempertahankan wisatawan lama dan menambah wisatawan baru.

\section{Uji Validitas dan Reliabilitas Quesioner}

Hasil penelitian yang valid menurut Sugiyono (1999 : 109) yaitu bila terdapat kesamaan antara data yang terkumpul dengan data yang sesungguhnya yang terjadi pada obyek yang teliti, sedangkan instrument yang valid berarti alat ukur yang digunakan untuk mendapatkan data itu valid. Valid berarti instrument tersebut dapat digunakan untuk mengukur apa yang seharusnya diukur.

Sehubungan dengan hal tersebut, maka data yang terkumpul terlebih dahulu perlu dilakukan uji validitas atas setiap butir/item pertanyaan untuk membuktikan apakah item-item tersebut benar-benar telah mengungkapkan faktor atau indikator yang diteliti.

Sehubungan dengan hal tersebut, maka data yang terkumpul terlebih dahulu perlu dilakukan uji validitas atas setiap butir/item pertanyaan untuk membuktikan apakah item-item tersebut benar-benar telah mengungkapkan faktor atau indikator yang diteliti.

Untuk menguji apakah korelasi tersebut valid atau tidak, maka hasil uji r-hitung dibandingkan dengan $r$ tabel dengan taraf signifikan minimal $95 \%$. Bila $r$ hitung $>r$ tabel berarti item pertanyaan dapat dikatakan signifikan/valid. Namun bila $\mathrm{r}$ hitung < r tabel berarti korelasinya tidak valid. 
Ini berarti item tersebut harus dikeluarkan dari data semula dan selanjutnya perlu dihitung kembali uji korelasinya untuk mengetahui validitasnya lagi. Tabel di bawah ini menunjukkan hasil perhitungan uji validitasnya. Hasil uji validatas dapat dilihat Shale Item Total Correlation pada lampiran Reliabilitas

Tabel 8

\section{Hasil Uji Validitas}

\begin{tabular}{|l|c|c|c|}
\hline \multirow{2}{*}{ Variabel } & \multicolumn{3}{|c|}{ Korelasi } \\
\cline { 2 - 4 } & hitun & r- & tabl \\
g & Keteranga & n \\
\hline Aksesibilit & 0.575 & 0,27 & \\
as (XI) & 0 & 9 & Valid \\
\hline Fasilitas ( & 0.458 & 0,27 & \\
X2) & 0 & 9 & Valid \\
\hline Utilitas & 0.528 & 0,27 & \\
(X3) & 1 & 9 & Valid \\
\hline Atraksi & 0.354 & 0,27 & \\
(X4) & 0 & 9 & Valid \\
\hline Etika dan & & & \\
Estetika & 0.589 & 0,27 & \\
(X5) & 0 & 9 & Valid \\
\hline SDM (X6) & 0 & 9 & Valid \\
\hline Promosi & 0.423 & 0,27 & Valid \\
\hline
\end{tabular}

\begin{tabular}{|l|c|c|c|}
\hline$(\mathrm{X7})$ & 0 & 9 & \\
\hline Motivasi & 0.784 & 0,27 & Valid \\
Wisatwan & 3 & 9 & \\
(Y) & & & \\
\hline
\end{tabular}

Sumber : Data primer yang diolah

Tabel di atas memperhatikan seluruh item yang digunakan valid. Ini berarti keseluruhan item dapat digunakan dalam penelitian. Selanjutnya akan diteliti hasil uji reliabilitas.

Uji reliabilitas quesioner dilakukan dengan tujuan untuk mengetahui konsistensi derajat ketergantungan dan stabilitas dari alat ukur. Tinggi atau rendahnya, kuat atau lemahnya korelasi dapat ditentukan berdasarkan pada besar kecilnya nilai $r$ (koefisien korelasi) yang menurut alhusi (2002:157) adalah :

Tabel 9

Kategori Nilai Korelasi

\begin{tabular}{|c|c|c|}
\hline No. & $\begin{array}{c}\text { Nilai } \\
\text { korelasi }\end{array}$ & Kategori \\
\hline 1 & $0,00-0,20$ & Sangat rendah \\
\hline 2 & $0,21-0,40$ & Rendah / lemah \\
\hline 3 & $0,41-0,60$ & Sedang \\
\hline 4 & $0,61-0,80$ & Tinggi/erat/kuat \\
\hline 5 & $0,81-1,00$ & Sangat \\
\hline
\end{tabular}




\begin{tabular}{|c|c|}
\hline & $\begin{array}{c}\text { tinggi/sangat erat/ } \\
\text { sangat kuat }\end{array}$ \\
\hline
\end{tabular}

(Sumber : Alhusi; 2002)

Dari hasil uji reliability yang dilakukan dengan program statistik SPSS 12.0 didapat hasil Cronbach Alpha lebih besar dari 0,8 untuk kedelapan variabel yaitu aksesibilitas, fasilitas, utilitas, atraksi, etika dan estetika, SDM dan promosi.

Tabel 10

\section{Releabilitas Variabel}

\begin{tabular}{|c|c|c|}
\hline $\begin{array}{c}\text { Reliabilitas } \\
\text { Variabel } \\
\text { Variabel }\end{array}$ & $\begin{array}{c}\text { Koefisien } \\
\text { Reliabilitas } \\
\mathbf{~ s}\end{array}$ & $\begin{array}{c}\text { Keteranga } \\
\mathbf{n}\end{array}$ \\
\hline $\begin{array}{c}\text { Aksesibilita } \\
\text { s (XI) }\end{array}$ & 0.5431 & Reliabilitas \\
\hline $\begin{array}{c}\text { Fasilitas } \\
\text { (X2) }\end{array}$ & 0.5455 & Reliabilitas \\
\hline $\begin{array}{c}\text { Utilitas } \\
(\text { X3) }\end{array}$ & 0.4430 & Reliabilitas \\
\hline $\begin{array}{c}\text { Atraksi } \\
(X 4)\end{array}$ & 0.5005 & Reliabilitas \\
\hline $\begin{array}{c}\text { Etika dan } \\
\text { Estetika } \\
(X 5)\end{array}$ & 0.5747 & Reliabilitas \\
\hline SDM (X6) & 0.6271 & Reliabilitas \\
\hline
\end{tabular}

Volume 7, No. 1 Juni 2009

\begin{tabular}{|c|c|c|}
\hline $\begin{array}{c}\text { Promosi } \\
(\mathrm{X} 7)\end{array}$ & 0.4617 & Reliabilitas \\
\hline $\begin{array}{c}\text { Motivasi } \\
\text { Wisatawan } \\
\text { (X8) }\end{array}$ & 0.1534 & Reliabilitas \\
\hline
\end{tabular}

Sumber : data primer yang diolah

Berdasarkan tabel di atas, terlihat bahwa jawaban responden bervariasi antara tidak baik dan kurang baik, yang menunjukkan bahwa promosi yang dilakukan oleh Pihak pengelolah Kawasan Ekowisata Alam puca' yang meliputi : (1) Penyampaian Promosi, (2) frekuensi promosi, (3) Tingkat Keyakinan (4)Kelengkapan Informasi, (5) Daya Tarik Promosi, yang dilakukan masih sesuatu yang awam bagi calon Wisatawan, artinya tidak ada promosi yang dianggap menjadi patokan mereka untuk datang ke Kawasan ekowisata alam Puca'

Dari ke-5 (lima) indikator promosi tersebut, akan dirangkum secara umum bagaimana nilai rata-rata tanggapan responden terhadap promosi. Nilai rata-rata tersebuit berasal dari perolehan rata-rata promosi (lihat rata-rata rata promosi pada lampiran) yang kemudian diberi interval empat, yaitu 1,00-1,75 = tidak baik; 1,76 - 2,50 = kurang baik; 2,51- 
3,25 = baik; dan 3,26-4,00 = sangat baik.

Tabel 11

Nilai Rata-rata variabel Promosi

\begin{tabular}{|c|c|c|c|}
\hline Interval & Kategori & $\begin{array}{c}\text { Jumlah } \\
\text { Responden }\end{array}$ & $\%$ \\
\hline $1,00-$ & Tidak & & \\
1,75 & Baik & 29 & 60 \\
\hline $1,76-$ & Kurang & & \\
2,50 & Baik & 21 & 40 \\
\hline $2,51-$ & & & 0 \\
3,25 & Baik & 0 & 0 \\
\hline $3,26-$ & Sangat & & \\
4,00 & Baik & 0 & 0 \\
\hline
\end{tabular}

Sumber : Data Primer yang diolah)

Dari hasil uji reliability yang dilakukan dengan program statistik SPSS 12.0 didapat hasil Cronbach Alpha lebih besar dari 0,8 untuk kedelapan variabel yaitu aksesibilitas, fasilitas, utilitas, atraksi, etika dan estetika, SDM dan promosi.

\begin{tabular}{|c|c|c|}
\hline Estetika (X5) & & \\
\hline SDM (X6) & 0.6271 & Reliabilitas \\
\hline Promosi (X7) & 0.4617 & Reliabilitas \\
\hline $\begin{array}{c}\text { Motivasi } \\
\text { Wisatwan (Y) }\end{array}$ & 0.1534 & Reliabilitas \\
\hline
\end{tabular}

Sumber : data primer yang diolah
Tabel 4.17

\section{Releabilitas Variabel}

\begin{tabular}{|c|c|c|}
\hline $\begin{array}{c}\text { Reliabilitas } \\
\text { Variabel }\end{array}$ & $\begin{array}{c}\text { Koefisien } \\
\text { Reliabilita } \\
\mathbf{s}\end{array}$ & $\begin{array}{c}\text { Keteranga } \\
\mathbf{n}\end{array}$ \\
\hline $\begin{array}{c}\text { Aksesibilita } \\
\text { s (X1) }\end{array}$ & 0.5431 & Reliabilitas \\
\hline $\begin{array}{c}\text { Fasilitas ( } \\
\text { X2) }\end{array}$ & 0.5455 & Reliabilitas \\
\hline $\begin{array}{c}\text { Utilitas } \\
(\mathrm{X} 3)\end{array}$ & 0.4430 & Reliabilitas \\
\hline $\begin{array}{c}\text { Atraksi } \\
(\mathrm{X} 4)\end{array}$ & 0.5005 & Reliabilitas \\
\hline Etika dan & 0.5747 & Reliabilitas \\
\hline
\end{tabular}

\section{Pengaruh Kualitas Pelayanan /} SDM (X6) Motivasi Wisatawan (Y).

Hasil perhitungan analisis regresi berganda dengan bantuan program SPSS, diketahui bahwa koefisien regresi determinan partial (B) dan nilai koefisien determinasi parsia $\left(\mathrm{r}^{2}\right)$ untuk variabel SDM $(\mathrm{Xg})$ adalah sebesar 2,665 dan 0,042 (4,2\%) dengan angka yang ditanda positif. Ini berarti bahwa pengaruh kedua variabel. Yaitu variabel SDM (Xg) terhadap motivasi wisatawan (Y) 
adalah searah. Artinya apabila variabel SDM ditingkatkan kualitasnya, maka motivasi wisatawan juga akan meningkat. Sebaliknya, jika variabel SDM diturunkan, maka motivasi wisatawan juga akan menurun.

Nilai t-hitung untuk variabel ini sebesar 2,011 lebih besar dari t-tabel yaitu 1,658, sehingga menunjukkan bahwa pengaruh kedua variabel yaitu SDM (Xg) terhadap motivasi wisatawan (Y) adalah signifikan, yakni terdapat pengaruh antara keduanya.

Angka r2 pada variabel ini adalah 0,042, artinya kontribusi variabel SDM $(\mathrm{Xg})$ terhadap motivasi wisatawan (Y) adalah 4,2\%, dengan catatan faktor lain adalah konstan. Ini berarti bila ada perubahan dari variabel SDM sebesar 1 satuan, maka akan menyebabkan perubahan secara searah pada motivasi wisatawan sebesar $4,2 \%$ atau 0,134 (nilai koefisien regresi). Artinya jika SDM meningkat sebesar 1 satuan, maka motivasi wisatawan akan meningkat sebesar 4,2\% atau meningkat sebesar 0,134 sebaliknya, jika SDM diturunkan sebesar 1 satuan, maka motivasi wisatawan akan berkurang sebesar 4,2\% atau berkurang sebesar 2,665. hal ini akan berlaku jika diasumsikan bahwa variabel lainnya di anggap tetap.

\section{Pengaruh Variabel Promosi (X7) terhadap Motivasi Wisatawan (Y).}

Hasil perhitungan analisis Regresi Berganda dengan bantuan Program SPSS, diketahui bahwa koefisien regresi determinan partial (B) dan nilai koefisien determinasi parsial (r2) untuk variabel promosi (X7) adalah sebesar 0,968 dan 0,046 (4,6\%) dengan angka yang bertanda positif. Ini berarti bahwa pengaruh kedua variabel, yaitu variabel promosi (X7) terhadap motivasi wisatawan (Y) adalah searah. Artinya apabila promosi ditingkatkan kualitasnya, maka motivasi wisatawan juga akan meningkat. Sebaliknya, jika promosi diturunkan, maka motivasi wisatawan juga akan menurun.

Nilai t-hitung untuk variabel ini sebesar 8,495 lebih besar dari tabel yaitu 1,658 , sehingga menunjukkan bahwa pengaruh kedua variabel yaitu promosi (X7) terhadap motivasi wisatawan (Y) adalah signifikan, yakni terdapat pengaruh antara keduanya.

Angka r2 pada variabel ini 
adalah 0,046, artinya kontribusi variabel promosi (X7) terhadap motivasi wisatawan (Y) adalah $4,6 \%$, dengan catatan faktor lain adalah konstan. Ini berarti bila ada perubahan dari variabel promosi sebesar 1 satuan, maka akan menyebabkan perubahan secara searah pada motivasi wisatawan sebesar 4,6 atau 0,163 (nilai koefisien regresi), Artinya jika promosi meningkat sebesar 1 satuan, maka motivasi wisatawan akan meningkat sebesar 4,6\% atau meningkat sebesar 0,968. sebaiknya, jika promosi diturunkan sebesar 1 satuan, maka motivasi wisatawan akan menurun sebesar $4,6 \%$ atau menurun sebesar 0,968 .

\section{Pengaruh Etika Dan Estetika (X5) terhadap Motivasi Wisatawan (Y).}

Hasil perhitungan analisis Regresi Berganda dengan bantuan program SPSS diketahui bahwa koefisien regresi determinan partial (B) dan nilai koefisien determinasi parsila (r2) untuk variabel etika dan estetika (X5) adalah sebesar 7,499 dan $0,042(4,2 \%)$ dengan angka yang bertanda positif. Ini berarti bahwa pengaruh kedua variabel, yaitu etika dan estetika ditingkatkan kualitas pelayanannya, maka motivasi wisatawan juga akan meningkat. Sebaliknya, jika variabel etika dan estetika diturunkan, maka motivasi wisatawan juga akan menurun.

Nilai t-hitung untuk variabel ini sebesar 0,115 lebih besar dari t-tabel yaitu 1,658 , sehingga menunjukkan bahwa pengaruh kedua variabel yaitu etika dan estetika (X5) terhadap motivasi wisatawan (Y) adalah signifikan, yakni terhadap pengaruh antara keduanya.

Angka r2 pada variabel ini adalah 0,042, artinya kontribusi variabel etika dan estetika (X5) terhadap motivasi wisatawan (Y) adalah $4,2 \%$ dengan catatan faktor lain adalah konstan. Ini seperti bila ada perubahan dari variabel etika dan estetika sebesar 1 satuan, maka akan menyebabkan pengaruh kedua variabel. Yaitu variabel SDM (X6) terhadap motivasi wisatawan (Y) adalah searah. Artinya apabila variabel SDM ditingkatkan kualitasnya, maka motivasi wisatawan juga akan meningkat. Sebaliknya, jika variabel SDM diturunkan, maka motivasi 
wisatawan juga akan menurun.

Nilai t-hitung untuk variabel ini sebesar 2,011 lebih besar dari t-tabel yaitu 1,658, sehingga menunjukkan bahwa pengaruh kedua variabel yaitu SDM (Xg) terhadap motivasi wisatawan (Y) adalah signifikan, yakni terdapat pengaruh antara keduanya.

Angka r2 pada variabel ini adalah 0,042, artinya kontribusi variabel $\mathrm{SDM}(\mathrm{Xg})$ terhadap motivasi wisatawan (Y) adalah 4,2\%, dengan catatan faktor lain adalah konstan. Ini berarti bila ada perubahan dari variabel SDM sebesar 1 satuan, maka akan menyebabkan perubahan secara searah pada motivasi wisatawan sebesar $4,2 \%$ atau 0,134 (nilai koefisien regresi). Artinya jika SDM meningkat sebesar 1 satuan, maka motivasi wisatawan akan meningkat sebesar $4,2 \%$ atau meningkat sebesar 0,134 sebaliknya, jika SDM diturunkan sebesar 1 satuan, maka motivasi wisatawan akan berkurang sebesar 4,2\% atau berkurang sebesar 2,665. hal ini akan berlaku jika diasumsikan bahwa variabel lainnya di anggap tetap.

\section{Pengaruh Variabel Promosi (X7) terhadap Motivasi Wisatawan}

(Y).

Hasil perhitungan analisis Regresi Berganda dengan bantuan Program SPSS, diketahui bahwa koefisien regresi determinan partial (B) dan nilai koefisien determinasi parsial (r2) untuk variabel promosi (X7) adalah sebesar 0,968 dan 0,046 $(4,6 \%)$ dengan angka yang bertanda positif. Ini berarti bahwa pengaruh kedua variabel, yaitu variabel promosi (X7) terhadap motivasi wisatawan (Y) adalah searah. Artinya apabila promosi ditingkatkan kualitasnya, maka motivasi wisatawan juga akan meningkat. Sebaliknya, jika promosi diturunkan, maka motivasi wisatawan juga akan menurun.

Nilai t-hitung untuk variabel ini sebesar 8,495 lebih besar dari tabel yaitu 1,658 , sehingga menunjukkan bahwa pengaruh kedua variabel yaitu promosi (X7) terhadap motivasi wisatawan (Y) adalah signifikan, yakni terdapat pengaruh antara keduanya.

Angka r2 pada variabel ini adalah 0,046, artinya kontribusi variabel promosi (X7) terhadap motivasi wisatawan (Y) adalah 4,6\%, dengan catatan faktor lain adalah konstan. Ini berarti bila ada perubahan 
dari variabel promosi sebesar 1 satuan, maka akan menyebabkan perubahan secara searah pada motivasi wisatawan sebesar 4,6 atau 0,163 (nilai koefisien regresi), Artinya jika promosi meningkat sebesar 1 satuan, maka motivasi wisatawan akan meningkat sebesar $4,6 \%$ atau meningkat sebesar 0,968. sebaiknya, jika promosi diturunkan sebesar 1 satuan, maka motivasi wisatawan akan menurun sebesar 4,6\% atau menururun sebesar 0,968 .

\section{Pengaruh Etika Dan Estetika (X5) terhadap Motivasi} Wisatawan (Y).

Hasil perhitungan analisis Regresi Berganda dengan bantuan program SPSS diketahui bahwa koefisien regresi determinan partial (B) dan nilai koefisien determinasi parsila (r2) untuk variabel etika dan estetika (X5) adalah sebesar 7,499 dan $0,042(4,2 \%)$ dengan angka yang bertanda positif. Ini berarti bahwa pengaruh kedua variabel, yaitu etika dan estetika ditingkatkan kualitas pelayanannya, maka motivasi wisatawan juga akan meningkat. Sebaliknya, jika variabel etika dan estetika diturunkan, maka motivasi wisatawan juga akart menurun.

Nilai t-hitung untuk variabel ini sebesar 0,115 lebih besar dari t-tabel yaitu 1,658, sehingga menunjukkan bahwa pengaruh kedua variabel yaitu etika dan estetika (X5) terhadap motivasi wisatawan (Y) adalah signifikan, yakni terhadap pengaruh antara keduanya.

Angka r2 pada variabel ini adalah 0,042, artinya kontribusi variabel etika dan estetika (X5) terhadap motivasi wisatawan (Y) adalah 4,2\% dengan catatan faktor lain adalah konstan. Ini seperti bila ada perubahan dari variabel etika dan estetika sebesar 1 satuan, maka akan menyebabkan perubahan secara searah pada moti vasi wisatawan sebesar $4,2 \%$ atau 7,449 (nilai koefisien regresi). Artinya jika etika dan estetika meningkat sebesar 1 satuan, maka motivasi wisatawan akan meningkat sebesar 4,2\% atau meningkat sebesar 7,499, sebaliknya, jika etika dan estetika diturunkan sebesar satuan, maka motivasi wisatawan akan berkurang sebesar $4,2 \%$ atau berkurang sebesar 7,499. Hal ini akan berlaku jika diasumsikan bahwa 
variabel lainnya di anggap tetap.

\section{Pengaruh Variabel Atraksi}

Wisata (X4) terhadap Motivasi Wisatawan (Y).

Hasil perhitungan analisis Regresi Berganda dengan bantuan program SPSS, diketahui bahwa koefisien regresi determinan partial (B) dan nilai koefisien determinasi parsial $\left(\mathrm{r}^{\wedge}\right)$ untuk variabel atrasi wisata (X4) adalah sebesar 0,961 dan 0,045 $(4,5 \%)$ dengan angka yang bertanda positif. Ini berarti bahwa pengaruh kedua variabel, atraksi wisata (X4) terhadap motivasi wisatawan ekowisata alam Puca' (Y) adalah searah. Artinya apabila variabel atraksi wisata ditingkatkan kualitas dan kuantitasnya, maka motivasi wisatawan juga akan meningkat. Sebaiknya, jika variabel atraksi wisata diturunkan, maka motivasi wisatawan juga akan menurun.

Nilai t-hitung untuk variabel ini sebesar 5.667 lebih besar dari t-tabel yaitu 1,658, sehingga menunjukkan bahwa pengaruh kedua variabel yaitu atraksi wisata (X4) terhadap motivasi wisatawan ekowisata alam Puca' (Y) adalah signifikan, yakni terdapat pengaruh antara keduanya.

Angka $\mathrm{r}^{\wedge}$ pada variabel ini adalah 0,045 , artinya kontribusi variabel atraksi wisata (X4) terhadap motivasi wisatawan ekowisata alam Puca' (Y) adalah 4,5\%, dengan catatan faktor lain adalah konstan. Ini berarti bila ada perubahan atraksi wisata sebesar 1 satuan, maka akan menyebabkan perubahan secara searah pada motivasi wisatawan sebesar $4,5 \%$ atau 0,961 (nilai koefisien regresi). Artinya jika atraksi wisata meningkat sebesar 1 satuan, maka motivasi wisatawan akan meningkat sebesar $4,5 \%$ atau meningkat sebesar 0,961 . sebaliknya. Jika atraksi wisata diturunkan sebesar 1 satuan, maka motivasi wisatawan akan berkurang sebesar $4,5 \%$ atau berkurang sebesar 0,961. Hal ini akan berlaku jika diasumsikan bahwa variabel lainnya di anggap tetap.

\section{Pengaruh Variabel Fasilitas (X2) terhadap Motivasi Wisatawan (Y).}

Hasil perhitungan analisis Regresi berganda dengan bantuan program SPSS, diketahui bahwa koefisien regresi determinan partial 
(B) dan nilai koefisien determinasi parsial $\left(\mathrm{r}^{\wedge}\right)$ untuk variabel fasilitas (X2) adalah sebesar - 0,842 dan 0,041 $(4,1 \%)$ dengan angka yang bertanda negatif. Ini berarti bahwa pengaruh kedua variabel, yaitu variabel fasilitas(X2) terhadap motivasi wisatawan ekowisata alam Puca' (Y) adalah searah. Artinya apabila variabel fasilitas ditingkatkan, maka motivasi wisatawan ekowisata alam Puca' akan meningkat. Sebaliknya, jika variabel fasilitas diturunkan, maka motivasi wisatawan ekowisata alam Puca'akan meningkat, nilai t-hitung untuk variabel ini sebesar 1,993 lebih kecil dari t-tabel yaitu 1,658, sehingga menunjukkan bahwa pengaruh kedua variabel yaitu fasilitas (X2) terhadap motivasi wisatawan ekowisata alam Puca' (Y) adalah signifikan, yakni terhadap pengaruh antara keduanya, meski pengaruh yang terdapat bersifat negatif.

Angka r2 pada variabel ini adalah 0,043 artinya kontribusi variabel fasilitas (X2) terhadap motivasi wisatawan ekowisata alam Puca' (Y) adalah 4,3\%, dengan catatan faktor lain adalah konstan. Ini berarti bila ada perubahan harga sebesar 1 satuan, maka akan menyebabkan perubahan secara terbalik pada motivasi wisatawan ekowisata alam Puca' sebesar 4,3\% atau 0,162 (nilai koefisien regresi). Artinya jika fasilitas meningkat sebesar 1 satuan, maka motivasi wisatawan ekowisata alam Puca'akan menurun sebesar $4,3 \%$ atau 0,162. Hal ini akan berlaku jika diasumsikan bahwa variabel lainnya di anggap tetap. Sebaliknya, jika fasilitas diturunkan sebesar 1 satuan, maka motivasi wisatawan ekowisata alam Puca' akan meningkat. Sebesar 4,3\% atau meningkat sebesar 0,162.

\section{Penutup}

1. Kawasan ekowisata alam Puca' memiliki potensi pengembangan jauh lebih baik bila beberapa aspek-aspek yang ada di kawasan pengembangan tersebut, yakni aksesibilitas, fasilitas, utilitas, atraksi wisata, etika dan estetika, pelayanan (SDM) dan promosi diperhatikan dalam upaya pengembangannya, berdasarkan hasil analisis yang diperoleh, bahwa ke-7 faktor potensi pengembangan kawasan ekowisata alam Pucak tersebut secara 
bersama-sama

(simultan)

mempunyai pengaruh terhadap

jumlah pengunjung/wisatwan, adapun 5 (lima) factor yakni : aksesibilitas, fasilitas, utilitas, atraksi wisata, dan promosi , secara parsial mempunyai pengaruh yang signifikan terhadap motivasi wisatawan (nyata $=0,05$ ), sedangkan 2 (dua) factor lainnya, yaitu etika dan estetika dan pelayanan (SDM), mempunyai pengaruh terhadap motivasi wisatawan untuk berkunjung ke kawasan ekowisata alam Pucak tetapi pengaruh tersebut tidak signifikan (tidak secara nyata)

2. Dari hasil analisis diketahui bahwa, factor variable promosi adalah factor yang mempunyai pengaruh paling dominan diantara factor-factor variable bebas lainnya, dengan karakteristik regresinya sebesar $(0,968)$, hal ini diperkuat oleh nilai koefisien korelasi parsial sebesar $(\mathrm{r}=0,795$, secara kualitatif nilai koefisien korelasi ini tergolong tinggi dan bernilai positif, hal ini berarti bahwa orientasi hubungan yang searah antara promosi (X7) dengan motivasi wisatawan $(\mathrm{Y})$, ini berarti semakin baik tingkat promosi, maka motivasi wisatawan untuk berkunjung akan semakin meningkat nilai $\mathrm{t}$ hitung variable promosi sebesar $(8,49)$ lebih besar (>) dari nilai t table sebesar $(1,812)$ pada taraf nyata $=0,05$, dengan demikian dapat disimpulkan bahwa variable promosi (X7) mempunyai pengaruh yang signifikan terhadap jumlah pengunjung di kawasan ekowisata alam Pucak.

Dengan melihat kesimpulan diatas maka dapat penulis memberikan beberapa saran, yaitu diantaranya :

1. Mengingat factor promosi mempunyai yang paling dominan terhadap jumlah pengunjung / wisatawan di kawasan di kawasan ekowisata alam Puca', maka dalam rangka meningkatkan jumlah pengunjung perlu di upayakan lebih fokus lebih focus lagi memperkenalkan kawasan ekowisata alam pucak melalui berbagai media promosi. Upaya tersebut dapat dilaksanakan dengan cara :

- Memberikan informasi yang lengkap, benar dan dikemas 
secara menarik melalui brosur, leaflet dan melalui media, seperti $\mathrm{TV}$, radio, internet dan lain-lain.

- Mengadakan berbagai acara / event penting, seperti festival wisata, study tour, wisata tour dan lain sebagainya, yang dapat lebih memperkenalkan lagi kawasan ekowisata alam Puca' secara langsung dan lebih detail kepada para wisatawan.

- Bekerjasama dengan agen perjalanan, pemda dan masyarakat untuk mengadakan event kalender tahunan yang menjadi ajang dalam berbagai kegiatan dan lomba yang berhubungan secara langsung maupun tidak langsung dengan kegiatan wisata alam.

2. Walaupun faktor pelayanan (SDM) tidak mempunyai pengaruh yang signifikan (nyata) terhadap jumlah pengunjung/ wisatawan di kawasan ekowisata alam Puca', akan tetapi hal tersebut tidak bisa di abaikan begitu saja, karena factor pelayanan (SDM) mempunyai peranan yang cukup penting dalam mempengaruhi tingkat kepuasan dan motivasi pengunjung /wisatawan, oleh karena itu factor pelayanan (SDM) tersebut harus tetap menjadi perhatian semua pihak yang terkait, dengan kata lain kualitas pelayanan (profesionalisme) harus tetap ditingkatkan agar berdampak positif terhadap perubahan jumlah pengunjung.

3. Objek dan daya tarik wisata alam (ODTWA) yang dipasarkan saat ini masih bertumpu pada atraksi wisata buatan, seperti kolam pemancingan, kolam renang, bumi perkemahan (camping ground), penangkaran satwa, dan taman burung, sedangkan potensi utama yang dimiliki di Kawasan Ekowisata Alam Pucak, yakni daya tarik atraksi alamnya yang masih asli dan sangat potensial untuk dinikmati seperti air teijun Bontomanurung, arung jeram, jalur pendakian (tracking), pengamatan satwa endemik dan panorama alamnya perlu lebih di tingkatkan lagi dalam upaya pemanfaatan dan pengembangannnya. 


\section{E. Daftar Pustaka}

Julianti Paembonan, A, 2002, Analisa

Faktor-Faktor Yang

Mempengaruhi Pengembangan

Objek Wisata Tanjung Bunga

Kec. r, Tugas Akhir Planologi

Universitas “45” Makassar

R. G, Soekadijo, 1997. Anatomi Pariwisata, Gramedia, Jakarta

Oka A. Yuti., 1980. Pemasaran Pariwisata, Angkasa, Bandung

Oka. A. Yuti, 1980, Pengantar ilmu Pariwisata, Angkasa, Bandung

Suyitno, 1999. Perencanaan

Pariwisata, Penerbit kanisius, Jakarta

Prof. Ir. Kusudianto Hadinoto, 1996. Perencanaan Pengembangan destinasi Pariwisata, Universitas Indonesia, Jakarta

Janianton Damanik Dan Helmut F. Weber, 2006, Perencanaan Ekowisata, PUSPAR UGM \& Penerbit Andi Yokyakarta

Etty Rochaety, Ratih Tresnati, H. Abdul Majid Latief, 1998, Metode Penelitian Untuk Skripsi Dan Tesis, Raja Grafindo Persada, Jakarta

Undang-Undang Republik Indonesia No. 4 Tahun 1992, Tentang Perumahan dan Permukiman, Jakarta

Kantor Desa. Puca', 2006, Data Monografi Desa Puca' : Kab. Maros

2007Metodologi Penelitian Bisnis Dengan Aplikasi SPSS, Mitra Wacana Media, Jakarta Drs.Husein Umar, S.E.,M.M., M.B.A.,

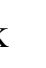

